\title{
Critical Discourse Analysis on Celebrity Case in Online News Headlines
}

\author{
Nadya Inda Syartanti \\ Universitas Brawijaya \\ Jl. Veteran Malang, Indonesia \\ nadya.inda.sy@gmail.com \\ Article History: Submitted on 20th April 2021; Accepted on 12th June 2021; \\ Published on 30th June 2021
}

\begin{abstract}
This study aims to reveal the construction of the news about the immoral video case that happened to Indonesia's celebrity (GA) in various online news media through Norman Fairclough's critical discourse analysis approach. Data sources are taken from various online news media, namely detik.com, kompas.com, liputan6.com, and tribunnews.com in the range of publications from November 2020 to January 2021 with the research subject in the form of news headlines related to GA's immoral video case. With three dimensions of discourse from Norman Fairclough's critical discourse analysis, the data analysis was carried out by the three stages: the descriptive analysis stage, the interpretation analysis stage, and the explanation analysis stage. The results found that through the microstructural dimension, the eight news headlines used language tools by 1) choosing vocabulary that was focused on the various phrase of video $X$, and 2) grammatical units which were dominated by clauses, 3) syntactic functions which were dominated by information as topicalization of discourse, and 4) a form of news that emphasizes the affirmation or clarification of GA's immoral video case. Then, through the mesostructure dimension, the four online mass media have different characteristics and characters in their delivery of news, especially news about the GA's immoral video case, but are still presented accurately and objectively so that the news content can be conveyed to readers. Finally, through the macrostructural dimension, with the reporting of immoral video cases, GA received a negative image in the eyes of the Indonesian people, because she was considered to be contrary to eastern culture. This negative image is formed because of the news using vulgar, tendentious, and transparent language to reflect press freedom that must be upheld, even though in composing news,
\end{abstract}


sometimes using sarcastic language and making comparisons in it to attract readers' interest.

Keywords: critical discourse analysis, GA, immoral video case, online news media

\section{INTRODUCTION}

The rapid development of communication technology cannot be separated from the easy access to obtain information autonomously. Communication, which used to take a long time to deliver, now with technology becomes very fast and seems without distance. Thanks to this technology, various media provide an alternative for people in finding and utilizing information sources to meet their needs (Hadi, 2010). Through the media, both individually and collectively, can build perceptions for other parties. Apart from being a tool for conveying news, images, or general descriptions of many things, the media can also act as a forum that can shape public opinion, even as a pressure group on ideas that must be accepted by other parties (Sobur, 2009).

Hall (Cenderamata \& Darmayanti, 2019) adds that the media have a significant role in explaining events and how they are interpreted and understood by the public. This can be seen from many media, primarily internet-based online media, to convey various information and news. With online media, now every individual has comprehensive access to various information and news about current events, one of which is about Indonesia's celebrities, such as the life of GA affected by the immoral video case. Information about celebrity life is constructed differently by several media according to the ideology of their respective media. To understand information, readers get different references according to the news that has been constructed by each of these media (Prihantoro, 2013). Therefore, this study will examine how various media construct news on the life of GA who is exposed to immoral video cases using Norman Fairclough's critical discourse analysis so that the news can be more accessible and more clearly understood.

Several previous studies related to this research have been carried out, including Cenderamata \& Darmayanti (2019) which analyzed the news about Mulan Jameela's hijrah published by four online media, namely detik.com, liputan6.com, tempo.com, and tribunnews.com through discourse critical analysis; Prihantoro (2013) who discussed the news about the arrest of Raffi Ahmad by BNN in four online media, namely kompas.com, mediaindonesia.com, detik.com, and liputan6.com through Norman Fairclough's critical discourse analysis; Dianastiti \& Mardikantoro (2016) who discussed news about the formation of teacher images in four newspapers, namely Harian Suara Merdeka, Harian Republika, Harian Kompas, and Tabloid Derap Guru through three dimensions of critical 
discourse analysis by Norman Fairclough, namely textual dimensions, discourse practice, and sociocultural dimension; Solikhati \& Mardikantoro (2017) who identify and analyze textual practices of corruption news discourse in two television media, namely Metro TV and NET through Norman Fairclough's critical discourse analysis; Mandarani, et.al. (2018) who examined the discourse on Rohingya reporting from three different media, namely VOA, the Jakarta Post version of the E-paper and CNN through Teun A. van Dijk's critical discourse analysis; and Kartikasari (2020) who traced the construction of news on the increase in BPJS contributions in the midst of a pandemic in six media, namely Kompas TV, SCTV, Indosiar, Tribunnews, cnnindonesia.com, and TV One using Norman Fairclough's critical discourse analysis.

The six studies have several similarities. First, the critical discourse analysis approach used is dominated by Norman Fairclough's approach as in research (Cenderamata \& Darmayanti, 2019; Dianastiti \& Mardikantoro, 2016; Kartikasari, 2020; Prihantoro, 2013; Sholikhati \& Mardikantoro, 2017), but only one study uses Teun A. van Dijk's approach to critical discourse analysis (Mandarani et al., 2018). Second, the data objects studied were taken from various forms of news media, both online media (Cenderamata \& Darmayanti, 2019; Prihantoro, 2013), print media (Dianastiti \& Mardikantoro, 2016), and television media (Sholikhati \& Mardikantoro, 2017). Third, even among these six studies, two studies used different forms of news media (Kartikasari, 2020; Mandarani et al., 2018). What is different from the six studies is that news topics are diverse and different from one another. Among the six studies, there are two studies from Cenderamata \& Darmayanti (2019) and Prihantoro (2013)'s research that took news topics around Indonesian celebrities' lives, which is similar to this study. However, although the two studies discuss the lives of Indonesian celebrities, both studies have not revealed the essence of Norman Fairclough's concept of critical discourse analysis, which is based on the big question, namely how to connect micro texts with macro contexts (Darma, 2013). In addition, no research discusses the case of Indonesian celebrities that went viral. Therefore, this study aim to reveal the construction of the headline news about the immoral video case that happened to GA in various online news media using critical discourse analysis by Fairclough's approach.

\section{METHOD}

The approach used in this study includes a qualitative descriptive methodological approach and a theoretical approach to Norman Fairclough's critical discourse analysis. To answer this, the object under study is mapped into three dimensions of discourse, namely 1) the textual (microstructural) dimension is an analysis of the text by looking at vocabulary, semantics, sentence structure, and cohesion and coherence 
between sentences; 2) the dimensions of the practice of discourse (mesostructural) are the practice of discourse by analyzing the processes of production, consumption, and distribution of texts; and 3) the socio-cultural dimension (macrostructural) is a socio-cultural practice that is analyzed using three levels, namely (a) situational, (b) institutional, and (c) social (Fairclough, 1995).

The data source used is the discourse on reporting the immoral video case that happened to GA in various online news media, namely detik.com, kompas.com, liputan6.com, and tribunnews.com in the range of publishing from November 2020 to January 2021. The data subject of this research is in the form of news headlines related to GA's immoral video cases, which are collected using the observation method and the proficient method followed by the conversation free observation technique, the recording technique, and the note-taking technique as data collection methods (Mahsun, 2014). The data analysis method was carried out by the three stages of discourse dimensional analysis in Norman Fairclough's critical discourse analysis, namely 1) the descriptive analysis stage which is describing the content and descriptive analysis of the text described; 2) the interpretation analysis, which is interpreting the text associated with discourse practice, where the text is not analyzed descriptively but is interpreted by relating it to how the text production process is; and 3) the explanation analysis aims to find an explanation for the results of the interpretation that have been carried out at the interpretation stage.

\section{FINDINGS AND DISCUSSION}

From the search results for news related to the case of immoral videos that happened to GA, several news headlines were found from several online news media as shown in table 1 below.

Table 1:

The Data of News Headline on the GA's Immoral Video Case

\begin{tabular}{|l|c|l|}
\hline \multicolumn{1}{|c|}{ Media } & Data & \multicolumn{1}{c|}{ News Headline } \\
\hline detik.com & 1 & $\begin{array}{l}\text { Fakta Terbaru Kasus Video Seks Mirip Gisel dari Polda } \\
\text { Metro Jaya (Latest Facts on Sex Video Cases Like } \\
\text { Gisel from Polda Metro Jaya) }\end{array}$ \\
\hline kompas.com & 2 & $\begin{array}{l}\text { Perjalanan Kasus Video Syur, Awalnya Gisel Mengelak } \\
\text { bingga Jadi Tersangka (The Journey of the Excitement } \\
\text { Video Case, Gisel Dodged At First then Became a } \\
\text { Suspect) }\end{array}$ \\
\hline liputan6.com & 3 & $\begin{array}{l}\text { Pernyataan Lengkap Permintaan Maaf Gisel Terkait Kasus } \\
\text { Video Syur (Gisel's Full Statement of Apology } \\
\text { Regarding The Excitement Video Case) }\end{array}$ \\
\hline liputan6.com & 5 & $\begin{array}{l}\text { Perjalanan Kasus Video Mesum Gisel hingga Jadi Tersangka } \\
\text { (The Journey of Gisel's Perverted Video Case to } \\
\text { Become a Suspect) }\end{array}$ \\
\hline
\end{tabular}




\begin{tabular}{|l|c|l|}
\hline & & $\begin{array}{l}\text { (Chronology of the Gisel's Excitement Video Case: } \\
\text { Initially Viral and Clarification, Then Becoming a } \\
\text { Witness, Now the Suspect is Together with MYD) }\end{array}$ \\
\hline tribunnews.com & 6 & $\begin{array}{l}\text { VIRAL Video Asusila Mirip Gisel \& Trending, Bukan } \\
\text { Kali Pertama, di Tabun 2019 Lalu Langsung Dibantah } \\
\text { (VIRAL Immoral Video Like Gisel \& Trending, Not } \\
\text { the First Time, in 2019 Then Immediately Denied) }\end{array}$ \\
\hline tribunnews.com & 7 & $\begin{array}{l}\text { 6 Fakta Kasus Video Syur Gisel dan MYD: Dibuat di } \\
\text { Medan Tabun 2017, Kini Jadi Tersangka (6 Facts on the } \\
\text { Excitement Video Case of Gisel and MYD: Made in } \\
\text { Medan in 2017, Now Become a Suspect) }\end{array}$ \\
\hline tribunnews.com & 8 & $\begin{array}{l}\text { Selain Minta Maaf, Ini Pengakuan Blak-blakan Gisel Usai } \\
\text { Diperiksa sebagai Tersangka Kasus Video Syur (Apart } \\
\text { from Apologizing, This is Gisel's Blunt Admission } \\
\text { After Being Examined as A Suspect in The } \\
\text { Excitement Video Case) }\end{array}$ \\
\hline
\end{tabular}

Table 1 shows that the news of GA's immoral video case has been in the news since GA stumbled on the same case in 2019 until GA stated an apology for the case. The reporting of GA's immoral video cases was analyzed based on three dimensions of Fairclough's critical discourse analysis: microstructural dimension, mesostructural dimension, and macrostructural dimension through three analysis stages: description, interpretation, and explanation, as shown in Figure 1 below.

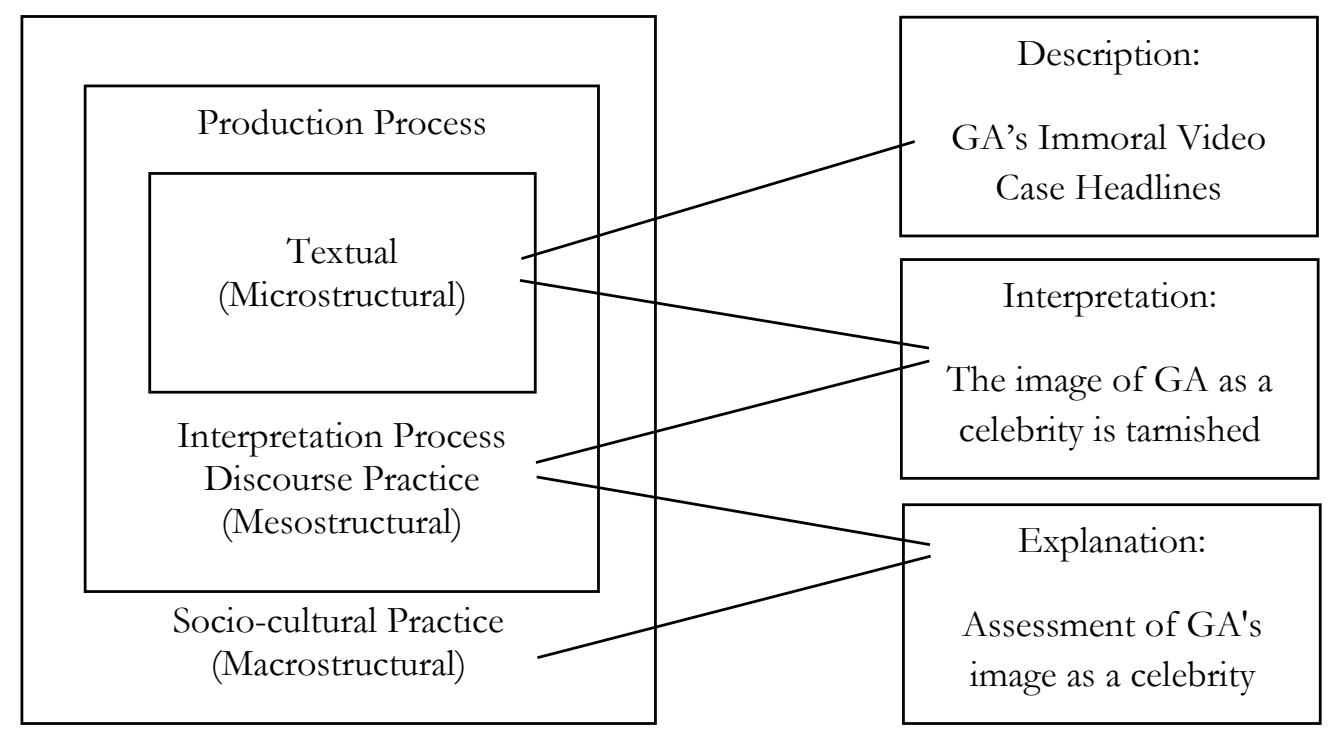

Figure 1:

Fairclough's Critical Discourse Analysis Framework in GA's Immoral Video Case 
With the Fairclough's critical discourse analysis framework, as shown in Figure 1, the reporting of GA's immoral video cases can be described one by one.

\section{Microstructural Dimension (Text Analysis)}

The microstructural dimension is analyzed based on the various language tools used by these media in reporting the GA's immoral video case, where two tools mark the representation of a person's theme, namely through (1) the selection of diction or vocabulary, and (2) grammatical units, syntactic function, and the form of news.

It was found that there were similarities in the headlines of the data (2), and data (4). However, even though they look similar, there are differences in the two headlines, namely the use of phrases video syur (exciting video), the adverb of awalnya (at first), and the verb of mengelak (dodge) in data (2), while in data (4) only appears in the use of phrases video mesum (perverted video).

In connection with the use of phrase video $X$ after the noun of video, it was found that there were differences in the choice of diction or vocabulary, namely video asusila (immoral video) in data (6), video mesum (perverted video) in data (4), video seks (sex video) in data (1), and video syur (excitement video) in data (2), (3), (5), (7), (8). It can be seen that the eight news headlines are more dominated by the use of phrase video syur (excitement video). The number of uses of the phrase video syur (excitement video) is inversely proportional to those listed in Kamus Besar Bahasa Indonesia (KBBI) (KBBI Online, 2021), that the word syur (excitement) is considered an archaic variety, that is, a variety of unusual word uses. This is understandable because the word syur (excitement) often appeared in the mass media in the 1980s and 1990s (Utami, 2014).

When observed in Kamus Besar Bahasa Indonesia (KBBI) (KBBI Online, 2021), the word syur (excitement) is included in two word classes, namely 1) as an adjective which means 'very attractive'; very interested in his/her heart; really like (to), and as a noun which means suggestion; advice. However, the word syur (excitement) used in the data (2), (3), (5), (7), and (8) belong to the adjective word class, so that the phrase of video syur (excitement video) can be mean as 'a fascinating video'. When viewed from its literal meaning, the adjective of syur (excitement) has a cheerful nuance of meaning. However, on the other hand, the adjective of syur (excitement) has the same negative nuance as the words asusila (immoral), kotor (perverted), and seks (sex). It can be found that the adjective of syur (excitement) often appears in semiporno magazines and tabloids that feature photos of women in excitement poses (Utami, 2014).

When observed in terms of grammatical units, the eight data are included in the units of phrases and clauses. Clause units are found in data (2), (4), (5), (6), (7), and (8), while the unit phrase is only found in data (1) and (3). The six data includes clause units because there are the use of verbs that function as predicates, namely active verbs of mengelak (dodge) (data 2), 
intransitive verbs of jadi (become) (data 4, 5, and 7), and passive verbs of dibantah (be refuted) (data 6), dibuat (be made) (data 7), and diperiksa (be examined) (data 8). From the three types of verbs, intransitive verbs are the most dominant verbs that used. The verb jadi (become) means ,menjadi" (to be) which is also included as a verb (KBBI Online, 2021). The verb menjadi (to be) has similar meaning with , sebagai" (as). This can be understood by adding the noun of tersangka (suspect) after the verb of jadi (become), so that the verb phrase of jadi tersangka (become a suspect) can be mean as 'as suspect ${ }^{6}$, where the noun of tersangka (suspect) is aimed at GA who is exposed to immoral video cases.

It was also found the presence of a syntactic function of description in the headline of data 2: Perjalanan Kasus Video Syur (The Journey of the Excitement Video Case); in the headline of data 5: Kronologi Kasus Video Syur Gisel (Chronology of the Gisel's Excitement Video Case); in the headline of data 6: VIRAL Video Asusila Mirip Gisel \& Trending (VIRAL Immoral Video Like Gisel \& Trending); in the headline of data 7: 6 Fakta Kasus Video Syur Gisel dan MYD (6 Facts on the Excitement Video Case of Gisel and MYD); and in the headline of data 8: Selain Minta Maaf (Apart from Apologizing) which all serves as a topicalization of discourse. The word of selain (apart from) in data (8) is identified as a form of an addition to GA's action after being declared a suspect in the immoral video case. The choice of words selain (apart from) being used to add information in the form of the latest facts that have been presented by the news writer regarding the immoral video case that happened to GA.

\section{Mesostructural Dimension (Discourse Practice)}

The mesostructure dimensions or discourse practice are focused on how text is produced and consumed. Text production is closely related to the ideology of news writers and the news media that supports it, in which there is discourse processing, such as the process of disseminating and using discourse, media profiles, editorial procedures, and the way workers produce news texts. The online news media discussed in this dimension are detik.com, kompas.com, liputan.com, and tribunnews.com.

The online news media of detik.com was founded on May 30, 1998, and is an internet-based news site that exists as a result of the changing times from the analog to the digital era. Then, on August 3, 2011, detik.com was officially acquired by Chairul Tanjung's Trans Crop. Detik.com does not have a print edition, it only has an online edition. Also, detik.com provides a lot of information for readers that are not limited in type, which presents news and provides service products, such as discussion services (detikForum) and advertising services (classified ads). With the variety of information presented by detik.com, it becomes a flexible site in cyberspace. This proves that detik.com can package the latest news, use neutral word choices, and be touched by all readers. Even the news about celebrities is 
presented by detik.com in an up-to-date manner and is packaged casually using short word choices that readers easily understand.

The online news media of kompas.com began with the print media Kompas which was published on June 28, 1965. At the beginning of its appearance, Kompas was the only print media that reported on politics and law. However, over time, information and entertainment sections were also featured in the printed media. Kompas has also published through online media with the site of kompas.com since July 1, 2009. Two years later, Kompas established an electronic media called Kompas TV which was founded on September 9, 2011. Presenting news on online media, kompas.com, used a certain column or channel according to the reader's needs. For example, in reporting cases of celebrities, kompas.com always looks at and directs the things readers have never thought of. Kompas.com invites its readers to directly assess an individual involved in a case. This is evidenced by using vocabulary that uses carefully and considerable reference of literature used in the news. This has become a characteristic as well as a character for kompas.com.

The online news media of liputan6.com began with the news program Liputan 6, which was founded on August 14, 2000, by PT Kreatif Media Karya, which presented television viewing-based news broadcast by SCTV. Liputan6.com has been present since May 24, 2012. The presentation of information in the form of news broadcasts has made liputan6.com present in the form of videos with the direction of coverage that looks at the aspect of crime. These present media news that is publicizing in detail highlights a case or event legally and according to the rules. However, liputan6.com does not focus much on the problems of celebrities, unless the celebrity commits a crime and is convicted of a criminal case, because this news media mainly presents news about actual crimes, sports, and politics.

Tribunnews.com is an online news media managed by PT Tribun Digital Online, Regional Newspaper Division Kompas Gramedia (Group of Regional Newspaper). This news site presents various kinds of news from various fields such as sports, economy, business, and lifestyle and celebrities that occur both local, national, and regional to international news with realtime and fast. Apart from being an online news site that provides electronic paper (e-paper) is a replica of a print edition newspaper, tribunnews.com also provides news in the form of digital paper, namely newspapers published online in digital format. Apart from print and online media, tribunnews.com also manages discussion forums and online communities via Facebook, Twitter, and Google+. This media is also known for its neat, actual and neutral news packaging using journalistic language that is following by the writing method. 


\section{Macrostructural Dimension (Sosio-Cultural Practice)}

The macrostructural dimension is a sosio-cultural practice analysis based on the opinion that the social context outside the media affects how discourse is in the media. Socio-cultural practices, such as the situational, institutional, and social levels affect media institutions and their discourse. First, situational level related to the production and context of the situation. Then, institutional level related to the influence of institutions internally and externally. Lastly, social level relates to more macro situations, such as political systems, economic systems, and society cultural systems.

Two news headlines have similarities in data (2) and data (4) that focused on topicalization of discourse related to the course of GA's immoral video case. Also, there are news headlines with the similar topicalization of discourse as the two news headlines in data (5). Although the choice of words used is kronologi (chronology) in data (5), this news headline also shows a series of immoral video cases that happened to GA and is emphasized by additional information on the sequence of events of GA's immoral video cases, namely Awalnya Viral dan Klarifikasi, Lalu Jadi Saksi, Kini Tersangka Bareng MYD (Initially Viral and Clarification, Then Becoming a Witness, Now the Suspect is Together with MYD). Considering that this case had occurred before in 2019 as shown in data (6), the public, especially GA fans, will feel disappointed with this news, making GA stumble with the same case. These four data show that there are sociocultural practices at the situational level because the reporting of GA's immoral video case occurred in 2019 until she became a suspect in 2020. However, the reporting of this case was taken from November 2020 to January 2021.

Socio-cultural practices at the institutional level are also found in two news headlines in data (1) and data (7). Both headlines are focused on the topicalization of discourse related to the facts of GA's immoral video case. The facts referred here are the findings investigated by the police regarding the GA's immoral video case. This can be seen in data (1), where information on the police institution is included in the headline, namely Polda Metro Jaya. On the other hand, although data (7) does not show any related institutions, information on police institutions is included in the news content. With the inclusion of the police institution as the investigating party in the case of GA's immoral videos, this can be categorized as an influence of the institution externally.

Socio-cultural practices at the social level are related to the society's cultural system. Indonesian culture is included in eastern culture. Eastern culture develops in Asia, such as countries in Southeast Asia, one of which is Indonesia. Eastern culture tends to be a form of culture that prioritizes politeness norms with specific rules (Sosiologi, 2020). Eastern cultural characteristics can be categorized to 1) simple; 2) self-control; 3) obeying existing norms; 4) adhere to religion; 5) tend to stay out of trouble; and 6 ) live together (Sosiologi, 2020). Among these characteristics, the culture of 
Indonesian society is dominated by the characteristics of obeying norms and adhering to religion. This is in contrast to the case that happened to GA. Indonesian society considers sex to be an act that is dirty, indecent, or immoral. Even for the Muslim community, doing sex before marriage is considered an act of adultery. Even though GA is a Christian, but because GA is part of Indonesian society, GA's actions have created a label, where the label becomes a cultured system in assessing a person's personality image. Finally, GA gets a negative image according to the Indonesian people's views, so it will be widely discussed and reported differently depending on specific motivations and opinions that the online mass media will image.

Reporting in vulgar, tendentious and open language reflects press freedom that must be upheld, although in composing news, sometimes using sarcastic language and making comparisons to attract readers' interest. The presence of the media in reporting the immoral video case of GA cannot be separated from the element of interest. The firm grip of the media in reporting determines whether the information broadcast to the public contains truth or falsity. The online news media used here is transformed into an extension of the hand to dominate the public. With the case that happened to GA, GA's figure indirectly made a negative impression in the public eye. The media tries to report objectively and transparently as a form of interest.

\section{CONCLUSION}

Based on Fairclough's critical discourse analysis through three dimensions of discourse, it can be concluded that through the textual microstructural dimension, the eight headlines use language tools with 1) choosing diction or vocabulary that is focused on various phrases of video $X$, and 2) grammatical units that are dominated by clauses, 3) a syntactic function that is dominated by information as topicalization of discourse, and 4) a form of news that emphasizes the affirmation or clarification of GA's immoral video case. Then, through the mesostructural dimension, the four online news media have different characteristics and characters in their delivery of news, especially news about the GA's immoral video case, but are still presented accurately and objectively so that the news content can be conveyed to readers. Finally, through the macrostructural dimension, with the reporting of immoral video cases, GA received a negative image in the eyes of the Indonesian people, because she was considered to be contrary to eastern culture. This negative image is formed because of the news using vulgar, tendentious, and transparent language to reflect press freedom that must be upheld, even though in composing news, sometimes using sarcastic language and making comparisons in it to attract readers' interest. 


\section{REFERENCES}

Cenderamata, R. C. \&, \& Darmayanti, N. (2019). Analisis Wacana Kritis Fairclough pada Pemberitaan Selebriti di Media Daring. Jurnal Literasi, 3(April), 1-8.

https://doi.org/http://dx.doi.org/10.25157/literasi.v3i1.1736.

Darma, Y.A. (2013). Analisis Wacana Kritis. Bandung: Yrama Widya.

Dianastiti, F. E., \& Mardikantoro, H. B. (2016). Analisis Wacana Kritis Pemberitaan Harian Suara Merdeka, Harian Republika, Harian Kompas, dan Tabloid Derap Guru dalam Pembentukan Citra Guru. Seloka: Jurnal Pendidikan Bahasa Dan Sastra Indonesia, 5(2), 136-147. https://doi.org/doi:10.15294/seloka.v5i2.13075.

Fairclough, N. (1995). Language and Power. London and New York: Longman.

Hadi, I. P. (2010). Perkembangan Teknologi Komunikasi Dalam Era Jurnalistik Modern. Scriptura, 3(1), 69-84. https://doi.org/10.9744/scriptura.3.1.69-84.

Kartikasari, S. (2020). Analisis Wacana Kritis Norman Faircluogh Terhadap Pemberitaan JOKOWI Naikkan Iuran BPJS di Tengan Pandemi. AnNida, 12(2). https://doi.org/https://doi.org/10.34001/an.v12i2.1608.

KBBI Online. (2021). Jadi. Retrieved from https://kbbi.kemdikbud.go.id/entri/jadi.

KBBI Online. (2021). Syur. Retrieved from https://kbbi.kemdikbud.go.id/entri/syur.

Mahsun. (2014). Metode Penelitian Bahasa: Tahapan Strategi, Metode, dan Tekniknya. Jakarta: PT Raja Grafindo Persada.

Mandarani, V., Nuroh, E. Z., Alfarisi, I. S., \& Eka, T. (2018). The Relation of Discourse Analysis About Rohingya News. English Language and Literature Conference (ELLiC), 2, 341-345. https://jurnal.unimus.ac.id/index.php/ELLIC/article/view/3552.

Prihantoro, E. (2013). Analisis Wacana Pemberitaan Selebriti Pada Media Online. Prosiding PESAT, 5(0), 8-9.

https://ejournal.gunadarma.ac.id/index.php/pesat/article/view/930.

Sholikhati, N. I., \& Mardikantoro, H. B. (2017). Analisis Tekstual dalam Konstruksi Wacana Berita Korupsi di Metro TV dan NET dalam Perspektif Analisis Wacana Kritis Norman Fairclough. Seloka: Jurnal Pendidikan Bahasa Dan Sastra Indonesia, 6(2), 123-129. 
https://doi.org/doi:10.15294/seloka.v6i2.17276.

Sobur, A. (2009). Analisis Teks Media: Suatu Pengantar untuk. Analisis W acana, Analisis Semiotik, dan Analisis Framing. Bandung: PT Remaja Rosdakarya Offset.

Sosiologi, D. (2020). V Pengertian Budaya Timur, Ciri, dan Contohnya DosenSosiologi.Com. Retrieved from https://dosensosiologi.com/budaya-timur/

Utami, A. (2014). Suatu Rasa Bernama Syur - Bahasa - majalah.tempo.co. Retrieved from https://majalah.tempo.co/read/bahasa/144604/suatu-rasa-bernamasyur. 